Another monopoly on the block

This month's sale of the telephone company British Telecom will not bring competition but may net the government $£ 4,000$ million. The objectives are admirable but the methods are wrong.

JUST as there is no general answer to the question how long is a piece of string, so there is no easy way of telling what a national telephone network may be worth. That may be the most charitable excuse for the stratagems to which the British Government has gone, in the past few months, for selling off 51 per cent of the shares in its nationalized telecommunications industry, now trendily called British Telecom. Last week, after an advertising campaign intended to interest men in the street in becoming shareholders (and which must have done more for general business education than decades of formal education), British Telecom and its merchant bank last week published the draft of the prospectus on which its shares will be sold on 28 November. The only missing ingredients in the prospectus are the price at which shares will be offered for sale, and the precise proportions that will be set aside for employees of the company, investors overseas and so on. Everybody is a little agog that on this one day, anything up to $£ 4,000$ million may change hands (although only 40 per cent of it will be payable on the nail).

While there is every reason to applaud the government's chief objective, that of introducing some of the self-balancing discipline of the marketplace into the regulation of a gigantic industry, suspicion must persist about its secondary objectives (balancing its budget by selling off its capital assets) and there are grave doubts about its methods.

The laudable primary objective is now quite widely shared. Only this year, the US telephone network, AT\&T, has been broken up into a number of smaller units, with geographically restricted monopoly rights. The Japanese Government is dickering with similar schemes. Everywhere, monopolistic telecommunications have become technically backward (or less technically advanced than they should be) and commercially slothful. Two quite separate tendencies have made the telephone monopolies indefensible. First, as experience in the United States has shown, allowing small companies to offer "value added services" by renting trunk circuits from the monopoly and selling on their use can benefit both the entrepreneurs and their customers. (The monopolies protest that these parasitic middlemen are merely skimming the cream off their legitimate business, to which the answer is that they should design their tariffs more intelligently.) Second, technology has often left the monopolies standing almost still and, in the past decade, with satellite communications in particular, has begun to raise the question whether telephone systems need now be the monopolies that seemed inevitable in the days of Alexander Bell. The British Government deserves some praise for recognizing that the time has come for change.

The British solution to the problem of the monopoly is at best half-hearted. There are three innovations. First, half of the telecommunications will in future be owned by private investors, not the government. The chief practical consequence will be that British Telecom will in future be able to raise capital from private sources without embarrassing the Treasury by inflating what is called the Public Sector Borrowing Requirement (which will assist technical innovation). Especially because the government promised, in last week's prospectus, not to vote its shares in ordinary circumstances, this change by itself is not a safeguard for the users of the network but, if anything, a device wherby the new owners can decide what profit they should be making. To guard against exploitation, there are two safeguards - a regulatory office (called Oftel) with powers to rule on complaints of unfair competition which has yet to show its teeth (but they look sharp) and a requirement imposed by the government that domestic telephone tariffs should not in the next five years increase by more than two per cent less than the inflation rate (which is meaningless, because the new corporation is almost certain to wish to finance a greater share of its development by borrowing than in the past). Third, there is a simulacrum of independent competition, a quite separate telecommunications network called Mercury.

The best that can be hoped for, in these novel circumstances, is that the competition will prosper. The worst possible outcome is unthinkable, for the political trouble there would be if Mercury should be in danger of collapse would have the government and the Bank of England at its side in a flash. (Perhaps the moral of last week's prospectus is to invest in Mercury, not British Telecom.) Meanwhile, the British Telecom prospectus cheekily reminds potential investors that the restriction of its tariffs laid down by the government will apply to only 45 per cent of its business. (To be fair, the rest includes international telephone traffic, where competition is likely in due course to be fierce, and the sale of equipment, where it is already cutthroat.)

Meanwhile, the question remains how much the business may be worth. The government's embarrassment is that there is no objective way of putting a value to its worth. The value of the income stream from a monopoly enterprise is not necessarily related to anything but the decisions taken by individuals as to what the profit should be. The value of the network's assets, calculated from the cost of providing them in the first place but abated by depreciation, may conceal as assets equipment so inefficient that, in a competitive world, it would be thrown away. One of the curious anomalies in last week's prospectus is the brief statement on depreciation policy, disclosing that British Telecom reckons on an average life of between 6 and 20 years for its old Strowger electromechanical equipment, but a uniform ten years for new digital equipment.

The sale now arranged has inevitably an air of unreality. Ultimately, what will matter is how much people are prepared to pay for half of British Telecom. The best way to have found out would have been to put the shares on sale in dribs and drabs, on exactly the pattern in which the government itself sells government stock. The way in which things have been arranged. however, is certain to cause embarrassment. If the shares on offer are not taken up, the government will be laughed at. If on the other hand, the shares sell like hot cakes, it will be accused of having given away a public asset. It has only itself to blame.

\section{Research competition}

\section{British universities had better become} knowledgeable about their research.

THOSE who think that the long agony of the British academic research enterprise must be coming to an end had better think again. That is the simple lesson to be drawn from last week's announcement by the Science and Engineering Research, Council that it is now embarked on finding fields of research or important 